\title{
Nephrology
}

\section{The Death of John Paul Jones and Resurrection as 'Father of the US Navy'}

\author{
Matthew R. Weir ${ }^{a}$ Lori L. Bogle ${ }^{c}$ Philip A. Mackowiaka, b \\ a Department of Medicine, University of Maryland School of Medicine, bVA Maryland Health Care System, \\ Baltimore, Md., and 'Department of History, United States Naval Academy, Annapolis, Md., USA
}

\section{Key Words}

'Father of the US Navy' • Kidney failure $\cdot \lg$ A nephropathy

\begin{abstract}
John Paul Jones, 'father of the US Navy', died under mysterious circumstances on July 18, 1792. Although his remains were resurrected and autopsied 113 years later, the cause of his death has yet to be explained fully. In this detailed review of his clinical history and autopsy findings, we conclude, as have others, that Jones died of kidney failure of undermined etiology. Although 'interstitial nephritis' was diagnosed by the prosectors who performed his autopsy, we believe glomerulopathy (possibly IgA nephropathy) was more likely responsible for his kidney failure and that his death was due to a cardiac arrhythmia or some other complication of uremia.

Copyright $\odot 2009$ S. Karger AG, Base
\end{abstract}

As far as we know, John Paul Jones (fig. 1) was in good health until 1770, when a severe fever sent him to bed for 16 days and left him 'much reduced'. Nothing more is known of the character of this illness or its treatment. He was 23, serving in the West Indies and recovered. Except for two other unnamed illnesses and recurrent psychological highs and lows bordering on manic-depressive disorder, he seems to have been well for the next seven years [1].

In 1780 , after many months at sea, he complained his eyes were so sore that he was almost blind, and for a time

\section{KARGER}

Fax +4161306 1234 E-Mail karger@karger.ch www.karger.com
(C) 2009 S. Karger AG, Basel

0250-8095/10/0311-0090\$26.00/0

Accessible online at:

www.karger.com/ajn

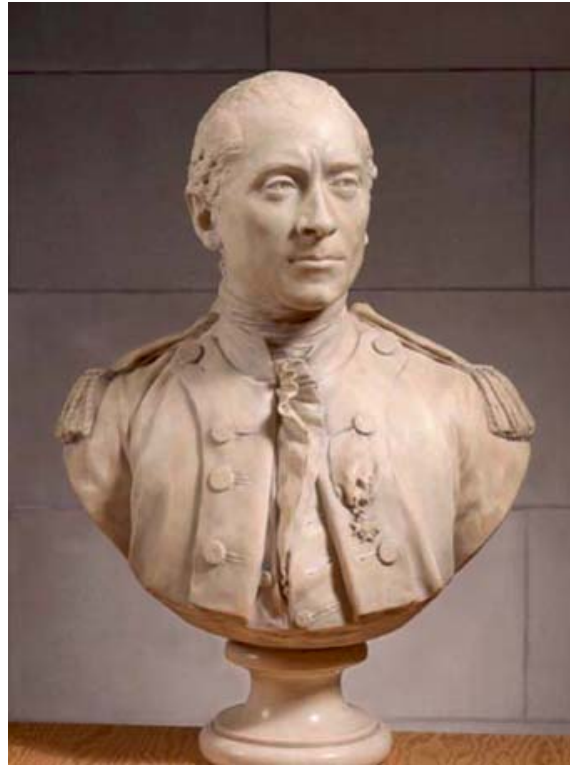

Fig. 1. White marble bust of John Paul Jones by Jean-Antoine Houdon (1747-1792) dated 1781 and generally regarded as the most accurate likeness of the subject (permission from the US Naval Academy Museum, Annapolis, Md.).

was so incapacitated that he gave up visiting friends on shore. His behavior then was 'Qweeg-like, suspicious and slightly dotty', and though only 33 , he felt like an old man. Three years later, during further service in the West Indies, a severe attack of 'tropical fever' caused him to trav- 


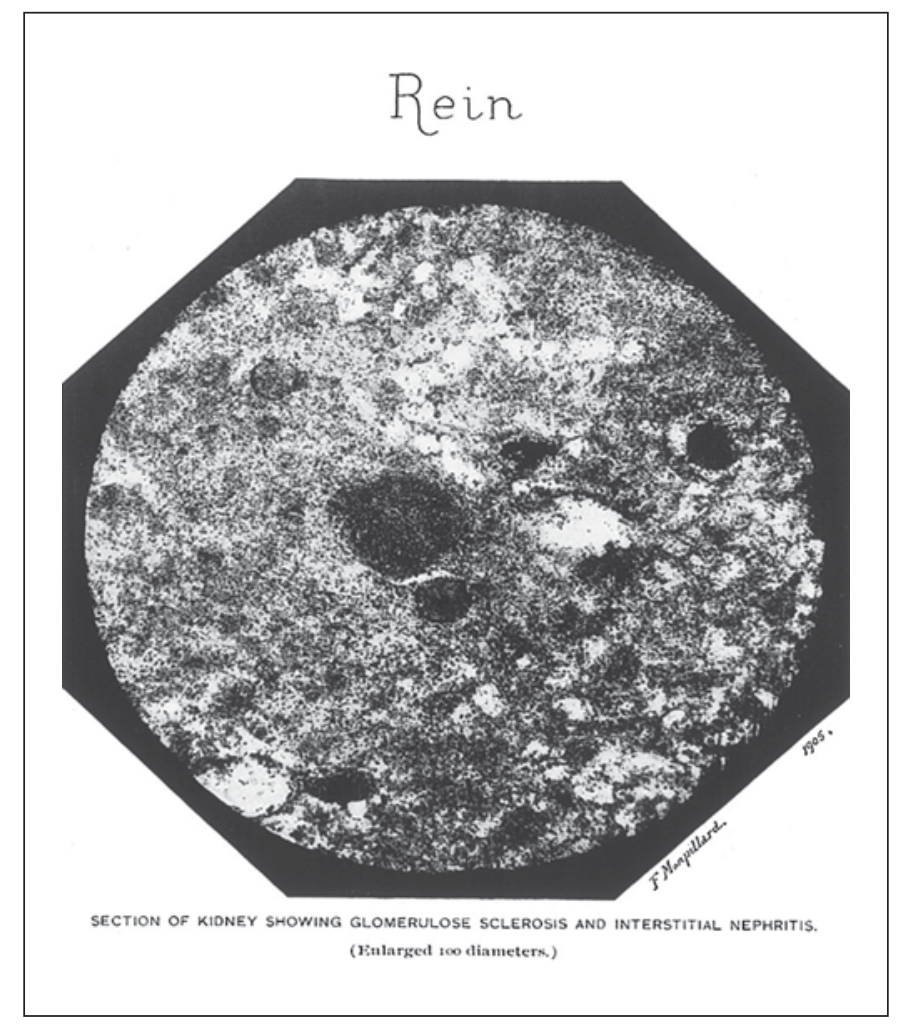

Fig. 2. Section of John Paul Jones' kidney prepared by Prof. Cornil and purportedly showing fibrosis of the glomeruli and interstitial nephritis (original magnification $\times 100$; permission from the US Naval Historical Center, Washington, D.C.).

el to a Moravian sanatorium in Bethlehem, Pa., for hydrotherapy, after which he recovered [1].

At the age of 41, Jones became ill during a frigid overland trip in an open carriage from Hamburg to Copenhagen. From Copenhagen, he traveled to St. Petersburg through ice floes in a small open boat to take command of a Russian fleet, arriving exhausted, sick and depressed. The illness lingered on for months. Although its specific characteristics are unknown, it is believed to have involved the lungs; afterwards, he had a persistent hacking cough and 'gray visage' [1].

Not much is known of Jones' family history. His father worked as a landscaper, his mother as a housekeeper. He had an older brother (a tailor) who died at the age of 36 of an unknown cause. Two sisters survived him. Nothing is known of their medical histories [1].

Although a veteran of numerous naval battles, Jones was never wounded. He never married and had no known offspring. His social life consisted of a tangle of love affairs involving myriad women ranging from prostitutes to grand dames. He avoided hard spirits, but in good weather would drink three glasses of wine after dinner [1].

Shortly before his 45th birthday, Jones' health declined precipitously. The nature of his final illness is described vividly in a letter written by a close friend, Col. Samuel Blackden, to Jones' sister shortly after the naval hero's death. In it, Blackden says of Jones:

But for two months past he began to lose his appetite, grew yellow, and showed symptoms of jaundice. For this he took medical treatment and for a short time seemed to grow better. A few days before his death his legs began to swell, which proceeded upward to his body, so that for two days before his decease he could not button his waistcoat and had great difficulty in breathing ... $[\mathrm{He}]$ put off the making of his will until the afternoon of July 18 , when he was prevailed upon to send for a notary and made his will. M. Beaupoil and myself witnessed it and left him sitting in a chair in his parlor. A few minutes after we retired he walked into his chamber and laid himself upon his face on the bedside, with his feet on the floor. The Queen's physician, who was attending him, came soon after, and on entering the apartment found him in that position, and on trying to lift him up found that he had expired. His disorder had terminated in dropsy of the heart. His body was put into a leaden coffin [and submerged in alcohol] on the 20th, that, in case the United States, which he had so essentially served and with so much honor, should claim his remains they might be more easily removed [2].

One hundred and thirteen years later (in 1905), the remains of John Paul Jones were recovered and autopsied. According to L. Capitan and Victor Cornil, who performed the autopsy:

The only organs which were injured were the kidneys (fig. 2). As far as can be judged, by examination of the badly preserved viscera [which included the heart, aorta, liver, gallbladder and spleen but not the brain], we believe that the case in point is interstitial nephritis, with fibrous degeneracy of the glomeruli of Malpighi, which quite agrees with the symptoms observed during life [3].

In elaborating further on the renal pathology, Dr. Cornil wrote that:

Sections of [the liver], slightly magnified, resembled perfectly those of a normal liver ... [The kidneys] revealed glomerulose lesions ... It is real interstitial glomerulitis far advanced on some glomeruli thus transformed into fibrous nodules. Moreover, the Bowmann capsules were at times much thickened. The arteries were likewise very thick and surrounded or filled with crystals of fat [4].

A search for tubercle bacilli in the lungs was negative. Only a small area of healed bronchopneumonia surrounded by fibrous tissue was identified in the left lung [4].

Thus, what we know of John Paul Jones' medical history is limited and does not permit definitive diagnosis of any of his illnesses. Moreover, his autopsy, which points to the kidneys as the seat of his final (fatal) illness, does 
not identify the specific disorder that destroyed them. Nevertheless, Jones' clinical record and postmortem examination provide enough details of the nature of his various illnesses to narrow the list of possible causes to just a few.

With regard to the series of illnesses that afflicted Jones between 1770 and 1783, most appear to have been infections contracted during service in the West Indies or possibly as a result of his intemperate sex life. Dengue or malaria would have been the most likely etiology of his severe and protracted illnesses during this period. Dengue is an especially attractive diagnosis for the illness of 1780 , in that it is commonly associated with intense retro-orbital pain (which might explain Jones' 'eyes so sore he was almost blind'), as well as marked fatigue, and muscle and joint pains (which could have accounted for his feeling 'like an old man' though only in his thirties) [5]. Leptospirosis is another diagnosis worth considering as the cause of that illness, both because it is commonly accompanied by conjunctivitis (which might explain the eye complaints) and also meningoencephalitis (which might have been the reason for Jones' 'Qweeg-like' behavior during the illness) [6].

With regard to sexually transmitted diseases - syphilis in particular - there is no doubt that John Paul Jones was at considerable risk for such infections. The prevalence of syphilis among the general population in both Europe and America during his life-time likely exceeded ten percent. Moreover, syphilis increases in frequency during war, and is most prevalent among prostitutes and their clients [7]. The extent of Jones' philandering (and hence, risk of having contracted syphilis) was apparently extraordinary, even by naval standards of his era [1]. Nevertheless, neither his clinical history nor his autopsy findings show evidence of syphilis.

The pulmonary problems that developed at the age of 41 during Jones' grueling journey to St. Petersburg were almost certainly manifestations of bacterial bronchopneumonia. Both his symptoms at that time and the results of his postmortem examination favor this diagnosis.

On postmortem examination, 'the only organs that were injured were the kidneys ... [which were] ... small, hard and contracted' [2]. Because the liver was 'normal, with its anatomical disposition very clear' [2], Jones' terminal ascites and peripheral edema are explained better by advanced renal failure, possibly complicated by the nephrotic syndrome, than by hepatic failure. Likewise, because the liver was apparently normal, the terminal 'jaundice' reported by Col. Blackden was more likely due to florid uremia, during which accumulation of carotenelike pigments combined with anemia gives the skin a yellow cast [8], than hyperbilirubinemia. If Jones was as uremic as these findings suggest, his precipitous demise likely would have been the consequence of a cardiac arrhythmia or some other fatal complication of uremia.

Based on the microscopic examination of the kidneys, Professor Cornil diagnosed both 'interstitial nephritis' and 'interstitial glomerulitis' [2]. Thus, what he appears to have seen in the microscopic sections of Jones' kidneys (which have since been lost) was generalized 'interstitial inflammation', which can be seen in the advanced stages of both chronic interstitial nephritis and glomerulonephritis.

If the admiral's fatal kidney disorder was chronic interstitial nephritis, as has been espoused since his autopsy in $1905[2,9,10]$, the question remains as to its etiology. Today, urinary obstruction, urinary reflux, analgesics, heavy metals and arteriolar nephrosclerosis are the principal causes of chronic interstitial nephritis [11]. Because Jones' renal arterioles appeared 'very thick' at postmortem examination [2], arteriolar nephrosclerosis is worth considering as a condition which might have resulted in chronic interstitial nephritis. The absence of obvious left ventricular hypertrophy, however, argues against this diagnosis, since 'sustained significant hypertension' is both the hallmark of the disorder and the mechanism by which it produces diffuse tubulointerstitial damage [11].

Given the lack of a history of analgesic abuse and the absence of nephrolithiasis and urinary anatomical abnormalities on postmortem examination, the only other cause of chronic interstitial nephritis worth considering is heavy metal intoxication. Of such metals, lead is the one to which Jones would most likely have been exposed. Chronic lead intoxication, in fact, was epidemic in 18th century Europe, owing to, among other things, widespread use of lead as a preservative in wine [12]. Jones consumed wine sparingly. Moreover, he had none of the other manifestations of chronic lead intoxication, such as obstipation, recurrent abdominal pain or peripheral neuropathy.

Because the principal causes of renal failure in the 18th century might have been different from those of the present, care must be taken in extrapolating current experience to patients of that era. This caveat notwithstanding, glomerulonephritis is presently substantially more common than interstitial nephritis. We believe that this fact combined with Jones' peripheral edema and ascites (which raise the possibility of nephrotic syndrome) and 
the absence of an obvious risk factor for interstitial nephritis render this diagnosis less likely than a chronic glomerular disorder.

In clinical practice today, the most common glomerular disorder of adults is IgA nephropathy, followed by membranous nephropathy, focal segmental glomerulosclerosis and diabetes. Recently reported histological evidence of IgA nephropathy in Crown Prince Joseph Habsburg, who died in 1847 [13], confirms the existence of the disorder in pre-modern times but, unfortunately, tells us nothing about its prevalence in Jones' life-time. If its relative importance as a cause of progressive glomerular disease has remained constant over the past two hundred years, IgA nephropathy would be Jones' most likely diagnosis, based solely on its current relative frequency. Nevertheless, given the histological abnormalities described by Cornil [4], membranous glomerulonephritis, focal segmental glomerulosclerosis or membranoproliferative glomerulonephritis could also have destroyed the admiral's kidneys. The absence of a history of recurrent bouts of hematuria argues against IgA nephropathy, but might simply reflect the limitations of Jones' clinical record.

Initially considered a benign condition, IgA nephropathy is now recognized as a disorder that frequently progresses to renal failure. Its cause is unknown. Although infections (such as those to which John Paul Jones was exposed throughout his life) and environmental agents have long been suspected of inducing the immunological process responsible for IgA nephropathy, no such trigger has yet been identified. A wide variety of lesions have been encountered on light microscopy, including diffuse endocapillary proliferation, segmental sclerosis, segmental necrosis and cellular crescent formation. In addition to the glomerular alterations, a variety of nonspecific tubulointerstitial and vascular changes can be seen, including interstitial fibrosis, tubular atrophy, interstitial inflammation and vascular sclerosis [14]. Recent observations suggest that binding of immune complexes containing aberrantly glycosylated IgA1 to mesangial cells is responsible for these pathological alterations [15].

With regard to the question of the true 'father' of the United States Navy, no one person emerged as singularly worthy of the title in the aftermath of the American Revolution. Following the war, Jones left America embittered by a lack of recognition and served briefly as an officer in Catherine the Great's imperial fleet before fleeing Russia over an apparently trumped up rape charge. Hopeful of securing another naval commission, he traveled to Paris where he died in 1792, lonely and forgotten. Because the
American minister, Gouverneur Morris, refused to claim his body, a French official paid to have the corpse packed in straw and alcohol and sealed in a lead coffin for possible future transport to the United States. During the chaos of the French Revolution, the location of Jones' grave was soon forgotten [16].

Born John Paul (not Jones), the future admiral first went to sea at the age of 13 in a British merchant vessel because his family lacked the resources to pay the fees necessary for him to enter the Royal Navy. His nautical skills, social savoir faire and plain luck enabled him to work his way through the ranks on a series of ships until reaching captain at the remarkable age of 21 . His reputation suffered in 1773, however, after he killed a sailor (in Tobago), claiming self-defense during a mutiny. He fled rather than face trial, disappearing from the historical record until resurfacing in Philadelphia to join the Continental Navy at the outset of the American Revolution.

John Paul Jones, as he now called himself, was spectacularly successful as a naval commander. Unlike other officers engaged in privateering, he took the bold step, much to his crew's dismay, of attacking British war ships in their own waters. On September 23, 1779, he secured his place in American naval history with his celebrated victory over the powerful 44-gun HMS Serapis, while commanding a reconfigured East Indiaman, the Bonhomme Richard [16].

The official movement to recognize Jones as the 'father of the US Navy' began in 1900, when Augustus C. Buell published a two-volume biography titled Paul Jones: Founder of the American Navy [17]. Buell, an engineer turned historian, rewrote some of Jones' letters and completely fabricated other documents in promoting the naval commander's new exalted position. In 1904, President Theodore Roosevelt, inspired by Buell's biography and also by the discovery of Jones' corpse in an abandoned Parisian cemetery, publicly endorsed the admiral as the 'father of the Navy' [18-20]. Roosevelt, who had once dismissed Jones as merely a 'daring corsair', now enthusiastically embraced Augustus Buell's interpretation of the Jones legend as part of a publicity campaign to focus the country's attention on the importance of a powerful navy to America's role as an emerging world power. The campaign began on the anniversary of Jones' birth with an impressive memorial service at the American Church of the Holy Trinity in France. When the squadron carrying the admiral's remains arrived in Annapolis thirteen days later, the Naval Academy held a brief, but dignified, service before French and American pallbearers placed the casket in a temporary brick vault to await the full inter- 
national commemoration scheduled for the following spring [21]. In 1913, Congress finally appropriated the funds necessary to complete construction of a permanent resting place for the celebrated corpse - an ornate marble mausoleum reminiscent of Napoleon's in the basement of the Naval Academy chapel.

So who is the 'father' of the Navy? John Paul Jones, who had once written 'my desire for fame is infinite', certainly would have welcomed the title. The US Navy, however, believes the honor is more appropriately shared. Its current official position is that because many 'played prominent roles in the founding of a national navy ... the Navy recognizes no one individual as 'father' to the exclusion of all others ... The various attempts to credit individual naval officers with this act are misguided ....' Jones should be remembered in the Navy, according to the Naval Historical Center, 'for his indomitable will, his unwillingness to consider surrender when the slightest hope of victory still burned. Throughout his naval career Jones promoted professional standards and training. Sailors of the United States Navy can do no better than to emulate the spirit behind John Paul Jones's stirring declaration: "I wish to have no connection with any ship that does not sail fast, for I intend to go in harm's way" [22].'

\section{Acknowledgements}

This case discussion was presented in an open forum as one of a continuing series of historical clinicopathological conferences sponsored by the VA Maryland Health Care System and the University of Maryland School of Medicine. We are indebted to Larry Pitrof, Dr. Morton Kramer and the US Naval Academy for their assistance in bringing the conference to fruition, to Dr. Frank M. Calia for editorial advice, to Wayne Millan and John Wilson for historical information and to Dr. Cinthia Drachenberg for help in interpreting photographs of histological preparations of John Paul Jones' kidneys.

\section{References}

1 Thomas E: John Paul Jones: Sailor, Hero, Father of the American Navy. New York Simon \& Schuster, 2003,pp 1, 15-19, 30, 62, 212, 231, 232, 256, 283-303.

2 Porter H, Vignaud H, Gowdy JK, et al: Report of General Porter; in Stewart CW (ed): John Paul Jones: Commemoration at Annapolis April 24, 1906. Washington, US Government Printing Office, 1907, pp 49-79.

3 Capitan L: Report of Doctor Capitan; in Stewart CW (ed): John Paul Jones: Commemoration at Annapolis April 24, 1906. Washington, US Government Printing Office, 1907, pp 81-85.

4 Cornil V: Report of Professor Cornil; in Stewart CW (ed): John Paul Jones: Commemoration at Annapolis April 24, 1906. Washington, US Government Printing Office, 1907, pp 93-94.

5 Gubler DJ: Dengue and dengue hemorrhagic fever. Clin Microbiol Rev 1998;11:480-496.

-6 Berman SJ, Tsai CC, Holmes K, Fresh JW, Watten RH: Sporadic anicteric leptospirosis in South Vietnam. A study in 150 patients. Ann Intern Med 1973;79:167-173.
7 Mackowiak PA: Post Mortem. Solving History's Great Medical Mysteries. Philadelphia, ACP Press, 2007, p 224.

8 Epstein FH, Merrill JP: Chronic renal failure; in Thorn GW, Adams RD, Braunwald E, et al (eds): Harrison's Principles of Internal Medicine, ed 8. New York, McGraw-Hill Book Co., 1977, p 1435.

9 Vincent EH: Death comes for the admiral. Surg Gyn Obst 1949;89:779-783.

10 Lasky II: Autopsy of Admiral John Paul Jones 113 years postmortem: historic and forensic aspects. NY State J Med 1982;82:1110 1115.

11 Neilson EG, Kelly CJ: Chronic interstitial nephritis; in Kelly WN (ed): Textbook of Internal Medicine, ed 2. Philadelphia, J.B. Lippincott Co., 1992, pp 718-720.

12 Nriagu JO: Saturnine gout among Roman aristocrats. Did lead poisoning contribute to the fall of the empire? N Engl J Med 1983;308: 660-663.

13 Józsa LG: Histologic diagnoses of tissues from two nineteenth century Habsburgs. Paleopathol Newsl 2008;141:12-18.

14 Donadio JV, Grande JP: IgA nephropathy. N Engl J Med 2002;347:738-748.
15 Suzuki H, Moldoveanu Z, Hall S, et al: IgA1secreting cell lines from patients with $\operatorname{IgA}$ nephropathy produce aberrantly glycosylated IgA1. J Clin Invest 2008;118:629-639.

16 Bradford JC: The Reincarnation of John Paul Jones: The Navy Discovers Its Professional Roots. Washington, Naval Historical Foundation, 1986.

17 Buell AC: Paul Jones: Founder of the American Navy. New York, Charles Scribner \& Sons, 1900.

18 Field E: Paul Jones, founder of the American Navy, a history. The American Historical Review v. 6 1901, pp 589-590.

19 General Porter's Triumph. New York Times, April 16, 1905, p 4.

20 Theodore Roosevelt to Charles J. Bonaparte, 1 August 1905. Theodore Roosevelt Papers, Library of Congress, reel 338, series 2.

21 Marion H: John Paul Jones' Last Cruise and Final Resting Place: The United States Naval Academy. Washington, George E. Howard, 1906.

22 http://www.history.navy.mil/faqs/faq1131.htm 